Article

\title{
Impact of Sycamore Maple Thermal Treatment on a Granulometric Composition of Chips Obtained due to Processing on a CNC Machining Mentre
}

\author{
Richard Kminiak * 1 and Ladislav Dzurenda \\ Faculty of Wood Sciences and Technology, Technical University in Zvolen, 96053 Zvolen, Slovakia; \\ ladislav.dzurenda@tuzvo.sk \\ * Correspondence: richard.kminiak@tuzvo.sk; Tel.: +421-45-520-6369
}

Received: 30 November 2018; Accepted: 28 January 2019; Published: 30 January 2019

\begin{abstract}
This article deals with a granulometric composition of chips from the milling process of native and thermal treatment maple cuttings on a 5-axial Computer numerical control (CNC) machining center SCM Tech Z5. The aim of this article was to determine the changes in the granulometric composition of chips due to the thermal treatment of wood and to assess the potential risk of the creation of harmful dust fractions. Cuttings were milled with a shank cutter with exchangeable razor blades at feed speed $\mathrm{v}_{\mathrm{f}}=1 \div 5 \mathrm{~m} \cdot \mathrm{min}^{-1}$ and material removal $\mathrm{e}=3 \mathrm{~mm}$. The thermal treatment in order to modify the color of the maple wood was done with water vapour at temperatures of $\mathrm{t}_{\mathrm{I}}=112.5 \pm 2.5{ }^{\circ} \mathrm{C}$ for a period of $\tau=5.5 \mathrm{~h}$ (Mode I), $\mathrm{t}_{\mathrm{II}}=127.5 \pm 2.5{ }^{\circ} \mathrm{C}$ for a period of $\tau=6.5 \mathrm{~h}$ (Mode II), and $\mathrm{t}_{\mathrm{III}}=137.5 \pm 2.5^{\circ} \mathrm{C}$ for a period of $\tau=7.5 \mathrm{~h}$ (Mode III). The granulometric composition of the chips was detected by sifting. A granulometric analysis of the chips provided that more than $2 / 3$ of the produced chips are a coarse fraction consisting of flat chips with dimensions over $1 \mathrm{~mm}$. Dust fractions smaller than $500 \mu \mathrm{m}$ form isometric grains, i.e., chips having approximately the same size in all three dimensions. Inhalable dust particles, smaller than $125 \mu \mathrm{m}$, do not exceed a $2.5 \%$ share. The granulometric analysis of chips shows that the thermal treatment of maple wood does not create respirable fractions, and therefore, the thermal treatment of the wood does not have a negative impact on the living and working environments.
\end{abstract}

Keywords: dust particles; respirable fraction; working environment; effect of feed speed; effect of thermal treatment

\section{Introduction}

Wood is a complex and natural material that consists basically of cellulose (40-45\%), hemicelluloses (20-30\%), and lignin (25-35\%). Cellulose represents the crystalline area of the wood, whereas the structures of hemicelluloses and lignin make up the amorphous area. The main mechanical functions of hemicelluloses and lignin are to buttress the cellulose fibrils [1].

Wood materials can be degraded by attacks by numerous biological species and by environmental conditions, so they are protected by the use of various treatment processes. One of these processes is the thermal treatment of wood materials [2].

The thermal treatment of wood is an ecological method, as shown by References [3-5], which aims to temporarily or permanently modify the physical and mechanical properties of wood. One of the lasting physical changes is the color change of the wood [6-16].

CNC technologies have become an integral part of the woodworking industry. The CNC machining centers are among the most widely used ones. The 5-axial versions of these centers are trendy, as they, in addition to the basic movements in the $\mathrm{X}, \mathrm{Y}$, and $\mathrm{Z}$ axes, also allow rotational 
movements in the $\mathrm{B}$ axis (rotational movement around the $\mathrm{Y}$ axis) and $\mathrm{C}$ axis (rotational movement around the $\mathrm{Z}$ axis). The 5 -axial $\mathrm{CNC}$ machining centers are universal machines that allow machining of the workpiece within its five base areas and their combinations (the 6th area is reserved for the attachment of the workpiece during the machining process). The versatility of the 5-axial CNC machining centers has opened the issue of exhausting the chips from the working environment. Suction bins are used to exhaust the chips; the bins press against the workpiece surface and exhaust the sawdust into the air-conditioning system. Suction bins in the 5-axial version of the machines have taken on significant dimensions, and their volume reaches $0.125-0.350 \mathrm{~m}^{3}$ (there is a significant pressure loss created). Furthermore, the outlet of the suction bin is axial considering the technical feasibility point of view (while the movement of the produced chips is radial in most cases). The problem arises when the workpiece side edges are machined by the tools that are producing bigger chips. The separated chips are formed into a rotating air stream during the milling. The mixture of rotating air and chips has so much energy that its significant part is not carried by the exhausted air; it hits the walls of the suction bins and then falls into the workspace of the CNC machine so that the exhaust system cannot remove these chips. The practice is that the worker, after the final machining of the workpiece, "blows" out by the compressed air which causes secondary pollution of the working environment around the CNC machine $[17,18]$.

The formed chip is a polydispersive bulk mass consisting of coarse, medium coarse, and dust fractions. Wood dust with a grain size in interval 1-500 $\mu \mathrm{m}$ [19-26] is a hygroscopic, low abrasive, explosive bulk mass. The ratio of dust particles depends on the characteristics of the processed material, the parameters of the tool, as well as the technical and technological parameters of the machining process [27-33].

From a physiological point of view and according to the conventions in the sense of the international harmonization (USA: ACGIH and EPA; Europe: ISO, CEN, and BMRC) the dust fractions smaller than $100 \mu \mathrm{m}$ are divided as follows: breathable (inhalable) mass fraction $<100 \mu \mathrm{m}$, thoracal 5-10 $\mu \mathrm{m}$, tracheobronchial (respirable mass fraction) $2.5-5 \mu \mathrm{m}$, and high respirable mass fraction $<2.5 \mu \mathrm{m}$.

The main aim of this article is to determine the granulometric composition of the chips from machining thermally untreated maple wood and thermally treated maple wood on a 5-axial CNC machining center SCM TECH Z5 in real conditions in practice. The second aim of this article is to prove (verify) the influence of the thermal treatment of maple wood on the formation and production of the harmful dust fractions.

\section{Materials and Methods}

\subsection{Material}

In this experiment, natural and thermal treatment furniture cuttings with the following parameters were used: wood—sycamore maple (Acer pseudoplatanus L.)—thickness of $25 \mathrm{~mm}( \pm 0.5 \mathrm{~mm})$, width of $80 \mathrm{~mm}( \pm 0.5 \mathrm{~mm})$, length of $500 \mathrm{~mm}( \pm 1 \mathrm{~mm})$, and humidity at $10 \%( \pm 2 \%)$. The thermal treatment of maple wood with saturated steam for the purpose of staining the total volume of wood into the pale-brown, brown, and brown-red colorations was performed by the modes in Table 1.

Table 1. The regimes for the thermal treatment of the maple wood using saturated water steam.

\begin{tabular}{ccccccc}
\hline $\begin{array}{c}\text { Thermal Treatment } \\
\text { Regimes }\end{array}$ & \multicolumn{2}{c}{ Temperature of the Saturated Water Steam, ${ }^{\circ} \mathbf{C}$} & \multicolumn{2}{c}{$\begin{array}{c}\text { Duration Technological Process of Thermal } \\
\text { Treatment of Wood } \boldsymbol{\tau}, \mathbf{h}\end{array}$} \\
\cline { 2 - 7 } & $\boldsymbol{t}_{\min }$ & $\boldsymbol{t}_{\max }$ & $\boldsymbol{t}_{\mathbf{4}}$ & $\boldsymbol{\tau}_{\mathbf{1}}$-Stage I. & $\boldsymbol{\tau}_{\mathbf{2}}$-Stage II. & Total $\boldsymbol{\tau}_{\mathbf{1}}+\boldsymbol{\tau}_{\mathbf{2}}$ \\
\hline Mode I. & 110 & 115 & 100 & 4.5 & 1.0 & 5.5 \\
Mode II. & 125 & 130 & 100 & 5.0 & 1.5 & 6.5 \\
Mode III. & 135 & 140 & 100 & 5.5 & 2.0 & 7.5 \\
\hline
\end{tabular}




\subsection{Machine}

The experiment was realized on a 5-axial CNC machining center SCM Tech Z5 (Figure 1) from the manufacturer SCM Group, Rimini, Italy.

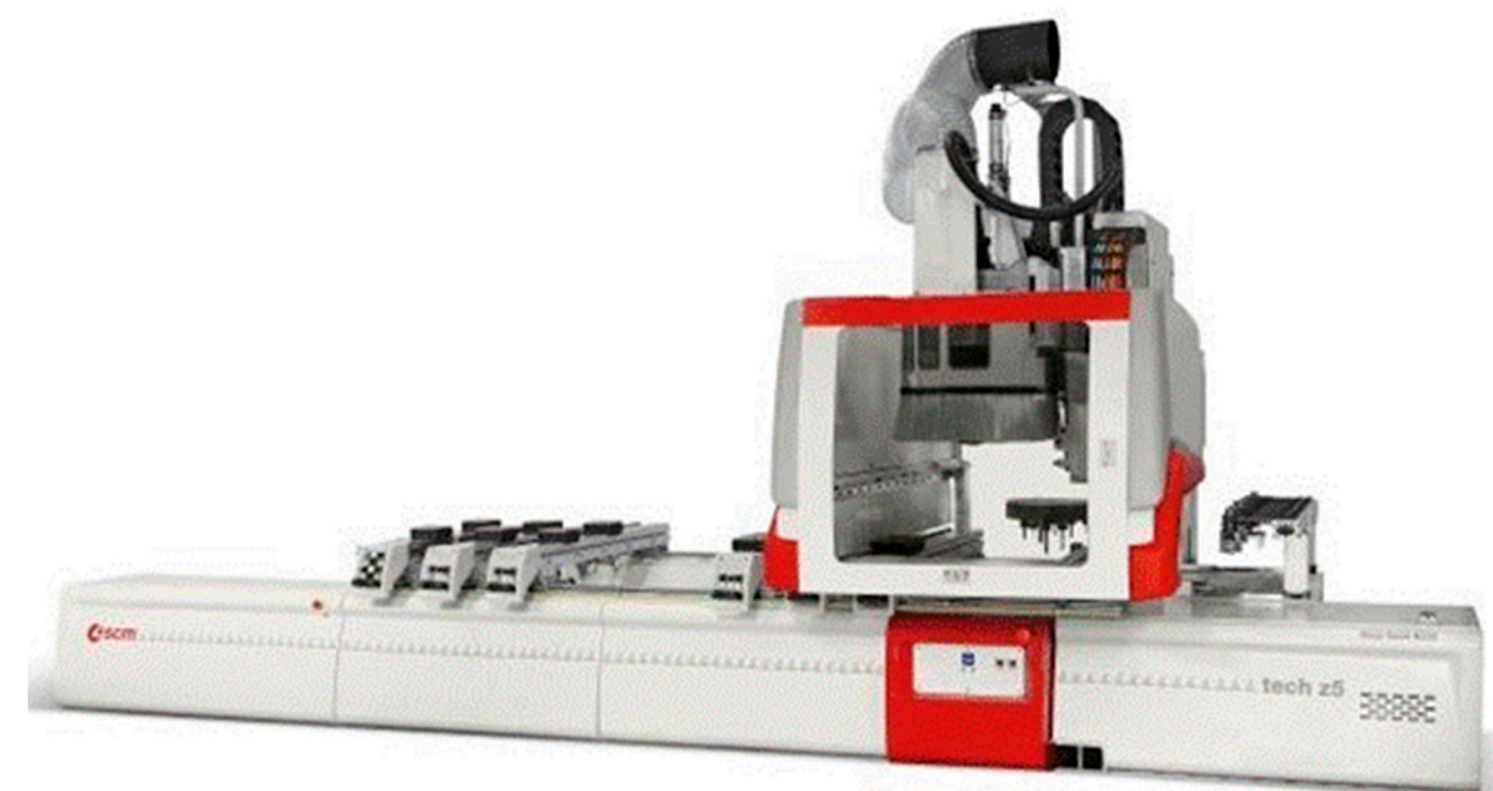

Figure 1. The CNC machining center SCM Tech Z5. CNC-Computer numerical control-it is a commonly used abbreviation, has already been used in the text before.

\subsection{Tool}

The single-shank cutter, type designation KARNED 4451, by the manufacturer Karned Tools Ltd., Prague, Czech Republic was used during the experiment (the tool was chosen with the assumption that it creates a chip of maximal dimensions copying the shape of the cut off chip). The reversible knife HW 49.5/9/1.5 from cemented carbide T10MG is fitted in the shank cutter.

\subsection{Milling Process}

The workpiece is milled within the following conditions: material removal $\mathrm{e}=3 \mathrm{~mm}$ (the amount of the removal is based on standard inputs of the processed materials), cutter speed $n=20,000 \mathrm{~min}^{-1}$ (this is the value recommended by the tool manufacturer), and feed speed $v_{f}=1,2,3,4$, and $5 \mathrm{~m} \cdot \mathrm{min}^{-1}$ (maximal feed speed recommended by a manufacturer is $5 \mathrm{~m} \cdot \mathrm{min}^{-1}$, but the operator adjusts/reduces the value to the level of $1 \mathrm{~m} \cdot \mathrm{min}^{-1}$ according to the local conditions of the milling process and the required quality of the created surface). For each combination of parameters, a milling process is performed on at least 6 samples until $3 \times 50 \mathrm{~g}$ of chips have been taken.

\subsection{Chips Removal}

The selected methods of chip removal reflect the requirements that it removes actual created chips and not only the chips that are possible to be removed by the suction device. The main exhaustion of the machine was off, and the collecting bin of the machine was lifted over the working space during the experiment. The main exhaustion of the machine was replaced by the preparation (Figure 2). The intake vacuum of the chips from the workspace was created by a mobile suction device OP 1500 from the Proma SK company, Zvolen, Slovakia (with a suction capacity $1020 \mathrm{~m}^{3} \cdot \mathrm{hr}^{-1}$, maximal intake vacuum $1400 \mathrm{~Pa}$, and suction pipe diameter $110 \mathrm{~mm}$ ). Exhausted chips were collected on the cloth filter Hyundai VCP 200 by Hyundai Mobis Co. Ltd., Yongin-Shi, South Korea (filter class G3: STN EN 779/1822). The chips collected on the cloth filter were dropped into the collecting bin, and when 
it reached the weight $\mathrm{m}=50 \mathrm{~g}$, it was taken up for further analysis. The intake port for sawdust exhausting was located at the site of the resulting direction of the sawdust stream. There were 3 samples of $50 \mathrm{~g}$ taken for each combination of parameters.
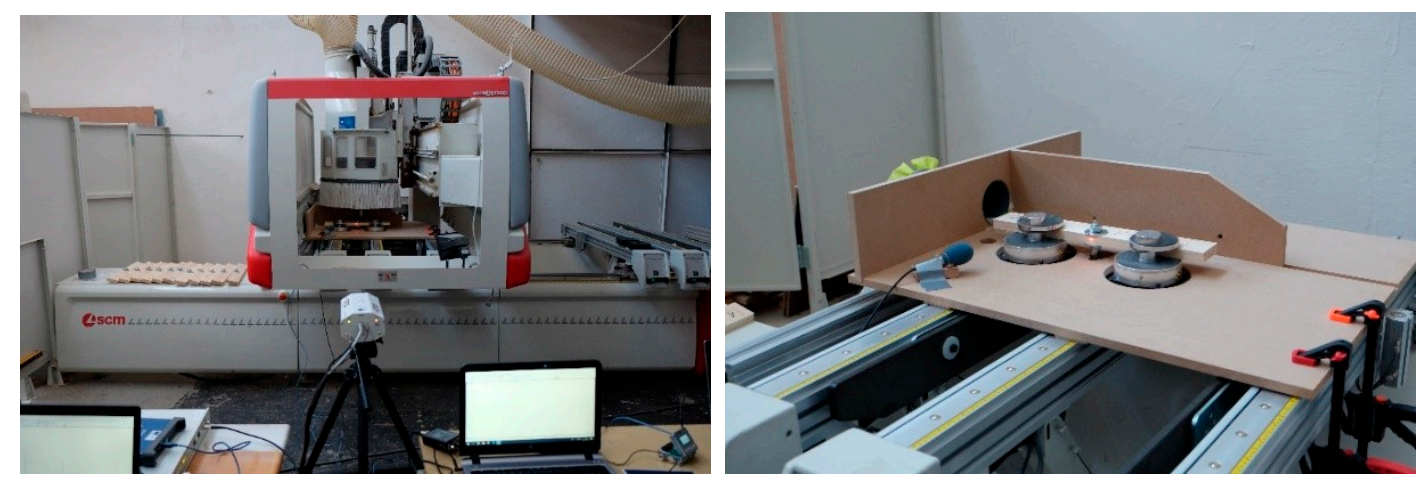

Figure 2. The preparation for removing the created chips.

\subsection{Granulometric Analysis}

A granulometric composition of the chips was detected by sifting. For this purpose, a special set of sieves arranged one above the other was used $(2 \mathrm{~mm}, 1 \mathrm{~mm}, 0.5 \mathrm{~mm}, 0.25 \mathrm{~mm}, 0.125 \mathrm{~mm}, 0.063 \mathrm{~mm}$, $0.032 \mathrm{~mm}$, and the bottom), and the sieves were placed on a vibration stand of the sifting machine Retsch AS 200c from the manufacturer Retsh $\mathrm{GmbH}$, Haan, Germany. The parameters of sifting were the following: the frequency of sifting interruption: 20 seconds, the amplitude of sieves deflection: $2 \mathrm{~mm} \cdot \mathrm{g}^{-1}$, the sifting time: $\tau=15 \mathrm{~min}$, and the weighed sample: $50 \mathrm{~g}$. The granulometric composition was obtained by weighing the portions remaining on the sieves after sifting on an electric laboratory scale Radwag 510/C/2 from the manufacturer Radwag Balances and Scales, Radom, Poland and weighed to an accuracy of $0.001 \mathrm{~g}$. The sifting was realized with 3 samples for each combination of parameters.

With the purpose of specifying the information about the size of the smallest particles of fine fraction of the dry sawdust, a microscopic analysis of the granules of fraction of the dry sawdust with a size lower than $125 \mu \mathrm{m}$ was realised. The proposed analysis of sawdust was carried out by an optical method: the analysis of the picture obtained from the microscope Nikon Optiphot-2 with the objective Nikon $4 \times$. Granules of sawdust were scanned by three low-cost television HITACHI HV-C20 (RGB $752 \times 582$ pixel) Charge Coupled Device (CCD) cameras with horizontal resolution 700 TV lines and were evaluated by a LUCIA-G 4.0 (Laboratory Universal Computer Image Analysis) software installed on a PC with the processor Pentium 90 (RAM 32 MB) and the graphics card VGA Matrox Magic under the operation system Windows NT 4.0 Workstation. The program of analysis of the picture, LUCIA-G, enables the identification of the individual particles of disintegrated wood material and the quantitative determination of individual particles situated in the analysed picture and of the basic information such as the width and length of particles and the circularity expressing the measure of deviation of the projection of a given chip shape from the projection of the shape of a circle according to the scheme:

$$
\psi=\left(4^{*} \pi^{*} \mathrm{~S}\right) / \mathrm{P}^{2}
$$

where $S$ is the surface of the particle $\left(\mathrm{m}^{2}\right)$ and $\mathrm{P}$ is the perimeter of particle $(\mathrm{m})$.

\section{Results}

The obtained data were subjected to a statistical analysis which did not confirm the dependence of the granulometric composition of the chips on the monitored parameters (degree of thermal treatment and strength of the feed force). 
The basic evaluation of the granulometric composition of the chips was done as a mixture of the chips from several feed speeds because there is a permanent change in the feed speed in the milling process at the $\mathrm{CNC}$ machining center.

The mixture of chips produced by the milling process of natural maple wood can be characterized as follows (Table 2 and Figure 3):

- the majority share $\left(64.25 \div 94.14 \%{ }^{* 1}\right)$ consists of fractions of over $2 \mathrm{~mm}$,

- the particle size $<500 \mu \mathrm{m}$ (dust particles) does not exceed $30.63 \%(5.33 \div 30.63 \% * 1)$,

- the particle size $<100 \mu \mathrm{m}$ (breathable dust fraction) does not exceed $0.95 \%(0.2 \div 0.95 \% * 1$ ),

- the particle size $<10 \mu \mathrm{m}$ (thoracal and tracheobronchial dust fraction) was not proven.

Table 2. The average granulometric composition of the chips for the individual combinations of the monitored parameters.

\begin{tabular}{|c|c|c|c|c|c|c|c|c|c|c|c|}
\hline \multirow{3}{*}{$\begin{array}{l}\text { Dimensions of Mesh } \\
\text { Sieve (mm) }\end{array}$} & \multirow{3}{*}{$\begin{array}{c}\text { Fraction } \\
\text { Designation }\end{array}$} & \multirow{2}{*}{\multicolumn{5}{|c|}{$\begin{array}{l}\text { Natural } \\
\text { eed } v_{f}=\left[\mathrm{m} \cdot \mathrm{min}^{-1}\right]\end{array}$}} & \multirow{2}{*}{\multicolumn{5}{|c|}{$\begin{array}{l}\text { Mode I. } \\
\text { geed } \mathrm{v}_{\mathrm{f}}=\left[\mathrm{m} \cdot \mathrm{min}^{-1}\right]\end{array}$}} \\
\hline & & & & & & & & & & & \\
\hline & & 1 & 2 & 3 & 4 & 5 & 1 & 2 & 3 & 4 & 5 \\
\hline $2 \mathrm{~mm}$ & \multirow{2}{*}{ coarse } & 94.14 & 80.24 & 69.38 & 72.43 & 64.25 & 83.78 & 84.55 & 66.97 & 75.52 & 83.31 \\
\hline $1 \mathrm{~mm}$ & & 2.52 & 1.50 & 6.19 & 4.28 & 5.12 & 2.40 & 0.76 & 3.61 & 3.97 & 4.13 \\
\hline $500 \mu \mathrm{m}$ & \multirow{3}{*}{ medium coarse } & 1.75 & 6.77 & 13.47 & 12.29 & 17.47 & 2.96 & 4.23 & 13.86 & 9.98 & 7.70 \\
\hline $250 \mu \mathrm{m}$ & & 1.63 & 7.95 & 7.77 & 9.13 & 10.50 & 4.82 & 6.49 & 12.29 & 8.82 & 3.57 \\
\hline $125 \mu \mathrm{m}$ & & 1.00 & 2.96 & 2.56 & 1.66 & 2.02 & 3.50 & 3.26 & 2.60 & 1.42 & 0.45 \\
\hline $63 \mu \mathrm{m}$ & \multirow{3}{*}{ fine } & 0.74 & 0.44 & 0.50 & 0.17 & 0.52 & 2.00 & 0.58 & 0.54 & 0.22 & 0.24 \\
\hline $32 \mu \mathrm{m}$ & & 0.22 & 0.15 & 0.12 & 0.04 & 0.12 & 0.54 & 0.14 & 0.13 & 0.07 & 0.10 \\
\hline$<32 \mu \mathrm{m}$ & & 0.00 & 0.00 & 0.00 & 0.00 & 0.00 & 0.00 & 0.00 & 0.00 & 0.00 & 0.00 \\
\hline \multirow{3}{*}{$\begin{array}{l}\text { Dimensions of Mesh } \\
\text { Sieve (mm) }\end{array}$} & \multirow{3}{*}{$\begin{array}{c}\text { Fraction } \\
\text { Designation }\end{array}$} & \multicolumn{5}{|c|}{ Mode II. } & \multicolumn{5}{|c|}{ Mode III. } \\
\hline & & \multicolumn{5}{|c|}{ Feed Speed $v_{f}=\left[\mathrm{m} \cdot \min ^{-1}\right]$} & \multicolumn{5}{|c|}{ Feed Speed $v_{f}=\left[\mathrm{m} \cdot \min ^{-1}\right]$} \\
\hline & & 1 & 2 & 3 & 4 & 5 & 1 & 2 & 3 & 4 & 5 \\
\hline $2 \mathrm{~mm}$ & \multirow{2}{*}{ coarse } & 96.27 & 82.01 & 74.95 & 66.64 & 81.57 & 89.22 & 85.85 & 67.76 & 69.36 & 74.56 \\
\hline $1 \mathrm{~mm}$ & & 0.32 & 0.69 & 4.66 & 6.31 & 5.28 & 0.91 & 1.51 & 5.07 & 8.30 & 4.50 \\
\hline $500 \mu \mathrm{m}$ & \multirow{3}{*}{ medium coarse } & 0.52 & 3.86 & 11.71 & 13.48 & 8.31 & 2.37 & 5.11 & 13.57 & 13.17 & 13.37 \\
\hline $250 \mu \mathrm{m}$ & & 1.03 & 7.99 & 6.74 & 11.17 & 4.27 & 4.04 & 5.53 & 10.21 & 7.28 & 6.21 \\
\hline $125 \mu \mathrm{m}$ & & 1.00 & 4.47 & 1.46 & 1.93 & 0.44 & 2.12 & 1.57 & 2.88 & 1.87 & 1.07 \\
\hline $63 \mu \mathrm{m}$ & \multirow{3}{*}{ fine } & 0.63 & 0.80 & 0.41 & 0.38 & 0.11 & 1.03 & 0.35 & 0.43 & 0.29 & 0.26 \\
\hline $32 \mu \mathrm{m}$ & & 0.22 & 0.18 & 0.07 & 0.09 & 0.01 & 0.31 & 0.08 & 0.08 & 0.03 & 0.02 \\
\hline$<32 \mu \mathrm{m}$ & & 0.00 & 0.00 & 0.00 & 0.00 & 0.00 & 0.00 & 0.00 & 0.00 & 0.00 & 0.00 \\
\hline
\end{tabular}

The mixture of chips produced by the milling process of thermal treatment maple wood by Mode I can be characterized as follows (Table 2 and Figure 3):

- the majority share $\left(66.97 \div 84.55 \%{ }^{* 1}\right)$ consists of fractions of over $2 \mathrm{~mm}$,

- the particle size $<500 \mu \mathrm{m}$ (dust particles) does not exceed $29.42 \%\left(12.06 \div 29.42 \%{ }^{* 1}\right)$,

- the particle size $<100 \mu \mathrm{m}$ (breathable dust fraction) does not exceed $2.54 \%\left(0.29 \div 2.54 \%{ }^{* 1}\right)$,

- the particle size $<10 \mu \mathrm{m}$ (thoracal and tracheobronchial dust fraction) was not proven.

The mixture of chips produced by the milling process of thermal treatment maple wood by Mode II can be characterized as follows (Table 2 and Figure 3):

- the majority share $\left(66.64 \div 96.27 \%{ }^{* 1}\right)$ consists of fractions of over $2 \mathrm{~mm}$,

- the particle size $<500 \mu \mathrm{m}$ (dust particles) does not exceed $27.05 \%(3.40 \div 27.05 \% * 1$ ),

- the particle size $<100 \mu \mathrm{m}$ (breathable dust fraction) does not exceed $0.85 \%\left(0.12 \div 0.85 \%{ }^{* 1}\right)$,

- the particle size $<10 \mu \mathrm{m}$ (thoracal and tracheobronchial dust fraction) was not proven. 


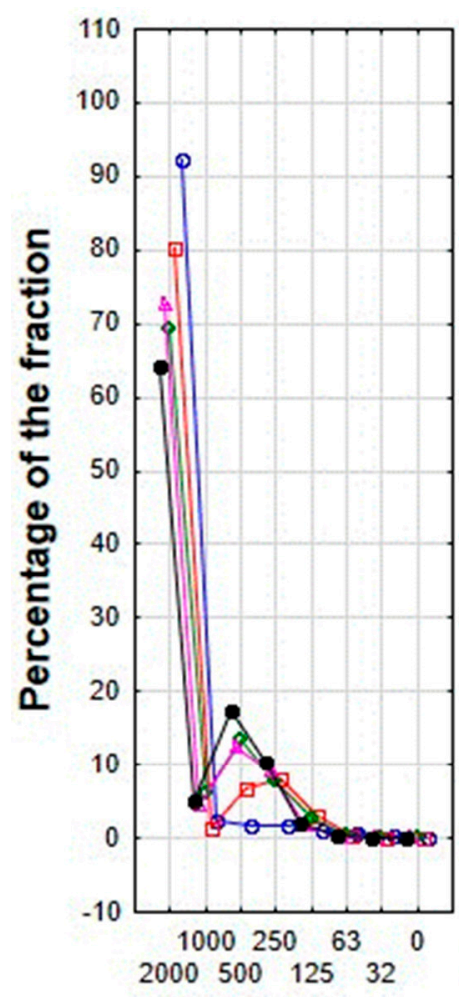

natural

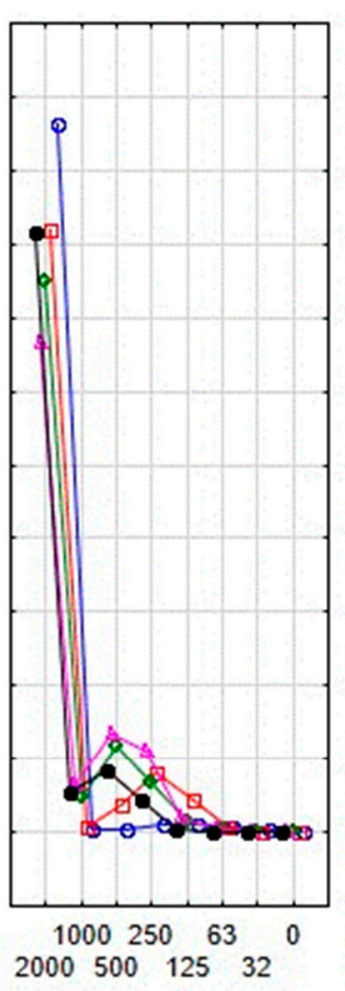

Mode I.

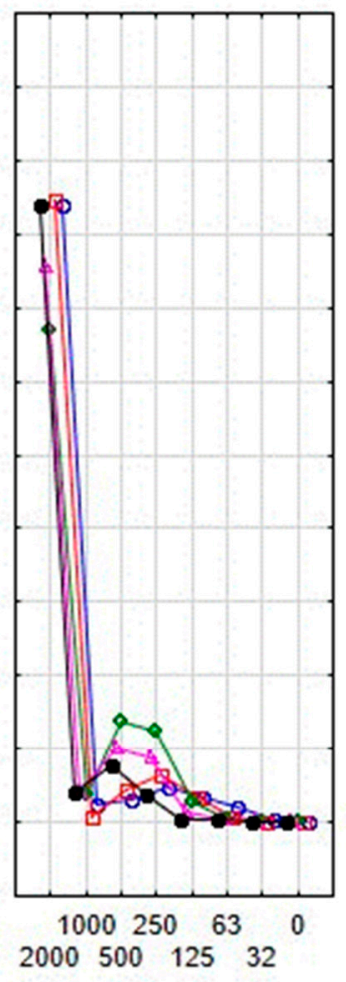

Mode II.

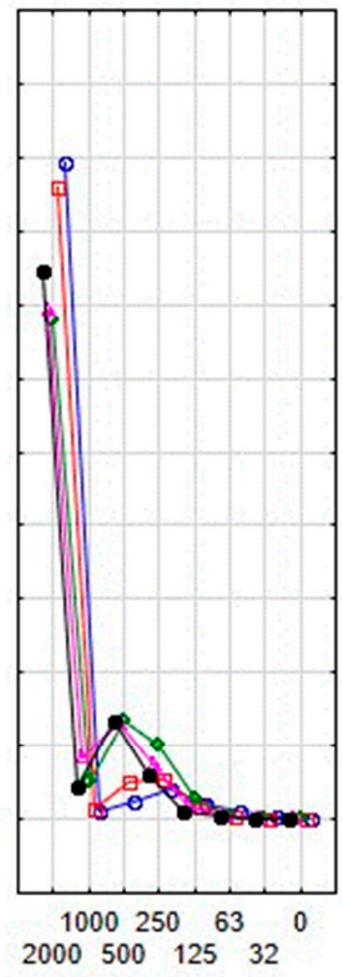

Mode III.

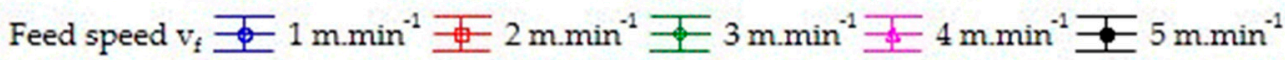

Figure 3. The average granulometric composition of the chips for the individual combinations of the monitored parameters.

The mixture of chips produced by the milling process of thermal treatment maple wood by Mode III can be characterized as follows (Table 2 and Figure 3):

- the majority share $(67.76 \div 89.22 \% * 1)$ consists of fractions of over $2 \mathrm{~mm}$,

- the particle size $<500 \mu \mathrm{m}$ (dust particles) does not exceed $27.17 \%(9.87 \div 27.17 \% * 1$ ),

- the particle size $<100 \mu \mathrm{m}$ (breathable dust fraction) does not exceed $1.34 \%\left(0.28 \div 1.34 \%{ }^{* 1}\right)$,

- the particle size $<10 \mu \mathrm{m}$ (thoracal and tracheobronchial dust fraction) was not proven.

$\left({ }^{* 1}\right.$ Depending on the feed speed)

The average values of the granulometric composition of the chips for all combinations of parameters are given in Table 2 with graphical representation presented in Figure 3.

The individual granulometric stages for all combinations of the examined parameters can be characterized in the following summary.

Fraction chips with dimensions over $2 \mathrm{~mm}$ belong to a category of flat chips, i.e., the length and width of the chip significantly exceed its thickness. The chip has the shape of a cut off layer of milled wood. At lower feed speeds, the chips are without breaks. With the increasing feed speed, the incidence of breaks increases. Fraction chips with the grain from $2 \mathrm{~mm}$ to $500 \mu \mathrm{m}$ belong to a category of fibrous chips, i.e., chips with a significant extension in one direction. Fractions smaller than $500 \mu \mathrm{m}$ can be characterized as isometric chips, i.e., chips having approximately the same size in all three dimensions. The inhalable dust fraction of particles smaller than $125 \mu \mathrm{m}$ represents the $0.6 \%$ share of natural, 0.71 $\%$ share of Mode I, $0.58 \%$, share of Mode II, and $0.57 \%$ share of Mode III. The CNC machining center does not produce respirable fractions smaller than $10 \mu \mathrm{m}$. 


\section{Discussion}

\subsection{Evaluations of the Thermal Treatment Effects}

Based on the available literature reviews, we have expected the statistically significant effect of the thermal modification on the granulometric chips' composition, namely reducing the share in fractions over $1 \mathrm{~mm}$ and increasing the share in fractions below $1 \mathrm{~mm}$; however this assumption has not been confirmed. An explanation of this effect is provided by a chemical analysis of the maple wood sawdust which shows that in the case of maple wood, comparing to, for example, beech wood, there are only minimal changes in the chemical structure of the wood. The most significant differences are in the hemicelluloses content. The content of hemicelluloses in thermally treatment wood species point to their different contents in maple and oak wood and also to the different degrading intensities (Figure 4). Both wood species show the greatest decrease in hemicelluloses in Mode III. While in maple wood, this difference was $6.4 \%$ and represented $19 \%$ of the original wood, in oak wood the difference was $22.9 \%$, which represented a decrease of up to $75.6 \%$. For both wood species, a similar course of lignin and polysaccharides ratio were also recorded [34].

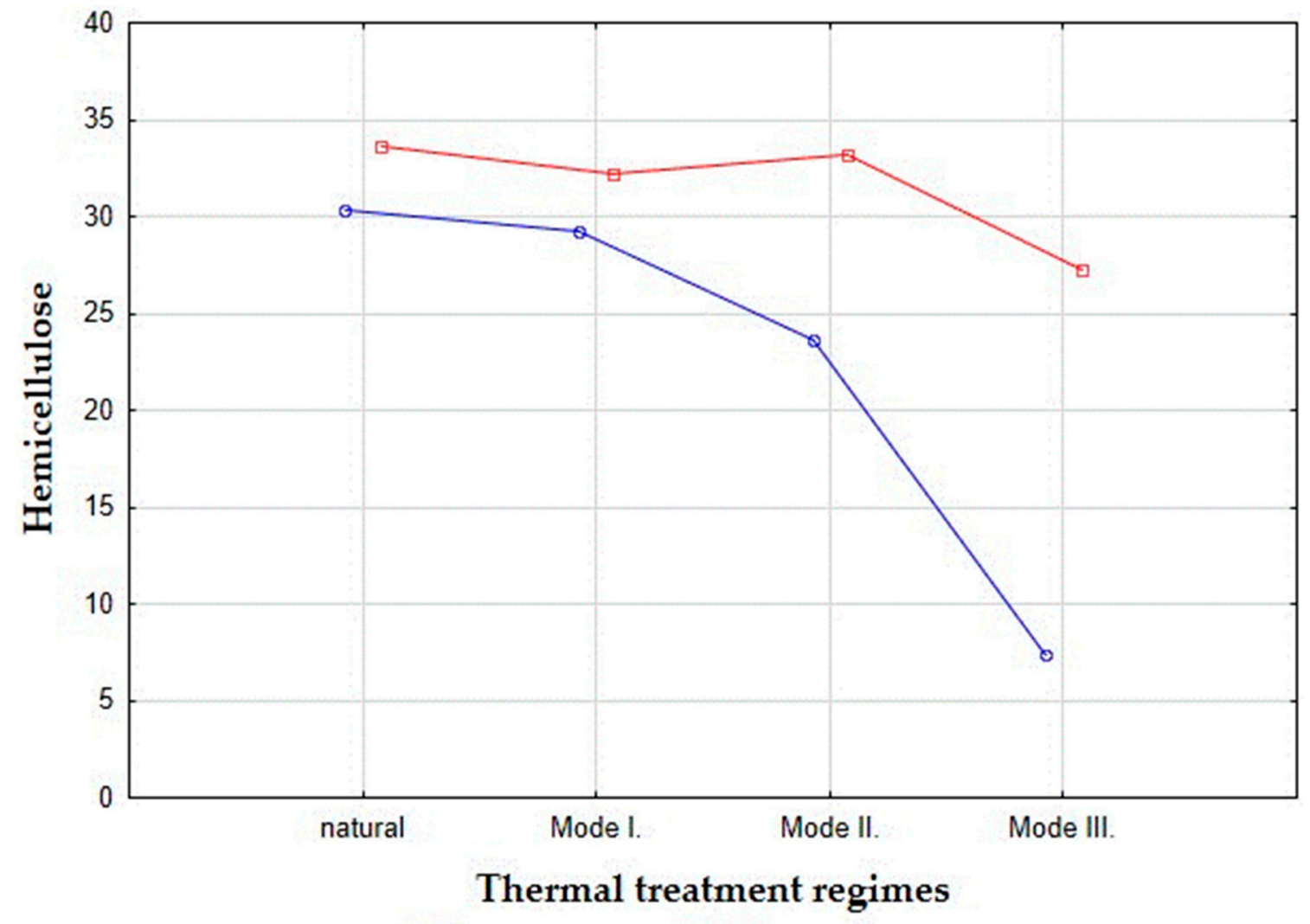

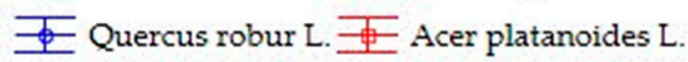

Figure 4. The hemicelluloses content before and after thermal treatment [34].

\subsection{Evaluation of the Feed Speed Effects}

The increase of feed speed is expected to cause a spall of chips, which is inconsistent with the statistical evaluation. For this reason, we realized an individual statistical evaluation of the obtained data for each granulometric stage. In the individual evaluations, the statistical dependence of the percentage representation of the fraction on the feed speed was proven. The change of feed speed caused the percentages of the individual fractions to regroup. This rearrangement essentially meant decreasing the percentage share of fractions over $2 \mathrm{~mm}$ and increasing the share of fractions below 1 $\mathrm{mm}$ and conversely. The increase was evident within the fractions 500 and $250 \mu \mathrm{m}$. Changes in the 
fractions $<125 \mu \mathrm{m}$ were only minimal (max $1.8 \%$ ). Significant finding is that even in one of the cases under consideration, there was no formation of chips $<32 \mu \mathrm{m}$.

This phenomenon corresponds with the milling theory, which links the nominal thickness of the cut off layer with the granulometric composition of the chips. The larger the chip thickness is, the more chips spall into particles, and there is an increase in the share of fine fractions of the chips. As can be seen in the work by Reference [18], the same dependence can be observed considering oak where the increase of the feed speed reduces the fraction share bigger than $2 \mathrm{~mm}$ and causes an increase in the share in fractions of $500 \mu \mathrm{m}$ and $250 \mu \mathrm{m}$.

The influence of the feed speed on the granulometric composition of the chips is difficult to generalize. The location of the minimum and maximum values in the matrix of the obtained results (Table 2) are variable by the feed speed, by the degree of thermal treatment, and by the particular granulometric stage.

In our opinion, fractions $<125 \mu \mathrm{m}$ are most significant because they represent risks to the working environment. It has been observed that their maximum percentage representation reached at low feed speeds and their minimum percentage representation reached at high feed speeds.

\section{Conclusions}

1. The obtained results did not confirm the assumption that the thermal treatment causes changes in the chemical structure that makes the wood so-called "more fragile" which can consequently cause a noticeable chip spalling and the increase of small fractions in the case of maple wood. The explanation is provided by a chemical analysis of the produced sawdust that showed only minimal changes in the crystalline cellulose.

2. Changing feed speed affects the rearrangement of the percentages of the individual fractions. The feed speed mainly affects a fraction $>2 \mathrm{~mm}$ and fractions $500 \mu \mathrm{m}$ and $250 \mu \mathrm{m}$. A reduction in the percentage of fractions $>2 \mathrm{~mm}$ causes mainly an increase in the percentage of fractions 500 $\mu \mathrm{m}$ and $250 \mu \mathrm{m}$ and conversely. The change of feed speed does not affect fractions $<32 \mu \mathrm{m}$.

3. Inhalable dust particles, smaller than $125 \mu \mathrm{m}$, do not exceed a $2.5 \%$ share.

4. An important finding is that the occurrence of particles below $32 \mu \mathrm{m}$ were not confirmed, and subsequently, the occurrence of particles thoracal $5 \div 10 \mu \mathrm{m}$, tracheobronchial $2.5 \div 5 \mu \mathrm{m}$, and high respirable mass fraction $<2.5 \mu \mathrm{m}$ were not confirmed too. Therefore, the thermal treatment of the wood does not have a negative impact on the living and working environments.

Author Contributions: Conceptualization, R.K. and L.D.; methodology, R.K. and L.D.; software, R.K.; validation, R.K; formal analysis, R.K. and L.D.; investigation, R.K. and L.D.; resources, R.K. and L.D..; data curation, R.K. and L.D.; writing-original draft preparation, R.K. and L.D.; writing—review and editing, R.K. and L.D.; supervision, L.D.; project administration, L.D.

Funding: This research was funded by project APVV-17-0456 “Thermal modification of wood with water vapor for purposeful and stable change of wood colour".

Acknowledgments: This experimental research was carried out under the grant project APVV-17-0456 "Thermal modification of wood with water vapor for purposeful and stable change of wood colour".

Conflicts of Interest: The funders had no role in the design of the study; in the collection, analyses, or interpretation of the data; in the writing of the manuscript; or in the decision to publish the results.

\section{References}

1. Wikberg, H.; Maunu, S.L. Characterisation of thermally modified hard and softwoods by ${ }^{13}$ C CPMAS NMR. Carbohydr. Polym. 2004, 58, 461-466. [CrossRef]

2. Bourgois, J.; Janin, G.; Guyonnet, R. Measuring colour: A method of studying and optimizing the chemical transformations of thermally treated wood. Holzforschung 1991, 45, 377-382. [CrossRef]

3. Požgaj, A.; Chovanec, D.; Kurjatko, S.; Babiak, M. Štruktúra a Vlastnosti Dreva; Príroda a.s.: Bratislava, Slovakia, 1997; p. 488. 
4. Dzurenda, L.; Deliiski, N. Analysis of moisture content changes in beech wood in the steaming process with saturated water steam. Drevarsky Vyskum 2000, 45, 1-8.

5. Kačíková, D.; Kačík, F. Chemické a Mechanické Zmeny Dreva pri Termickej Úprave [Chemical and Mechanical Changes of Wood during Thermal Treatment]; TU vo Zvolene: Zvolen, Slovakia, 2011; p. 71.

6. Bekhta, P.; Niemz, P. Effect of high temperature on the change in color, dimensional stability and mechanical properties of spruce wood. Holzforschung 2013, 57, 539-546. [CrossRef]

7. Timar, M.C.; Varodi, A.M.; Hacibektasoglu, M.; Campean, M. Color and FTIR analysis of chemical changes in beech wood (Fagus sylvatica L.) after light steaming and heat treatment in two different environments. BioResources 2016, 11, 8325-8343. [CrossRef]

8. Geffert, A.; Výbohová, E.; Geffertová, J. Characterization of the changes of colour and some wood components on the surface of steamed beech wood. Acta Facultatis Xylologiae Zvolen res Publica Slovaca 2017, 59, 49-57. [CrossRef]

9. Tolvaj, L.; Nemeth, R.; Varga, D.; Molnar, S. Colour homogenisation of beech wood by steam treatment. Drewno 2009, 52, 5-17.

10. Tolvaj, L.; Molnar, S.; Nemeth, R.; Varga, D. Color modification of black locust depending on the steaming parameters. Wood Res. 2010, 55, 81-88.

11. Deniz, A.; Gokhan, G.; Seray, O. The influence of thermal treatment on color response of wood materials. Color Res. Appl. 2012, 37, 148-153. [CrossRef]

12. Dzurenda, L. Modification of wood colour of Fagus Sylvatica L to a brown-pink shade caused by thermal treatment. Wood Res. 2013, 58, 475-482.

13. Dzurenda, L. The Shades of Color of Quercus robur L. Wood obtained through the processes of thermal treatment with saturated water vapor. BioResouces 2018, 13, 1525-1533. [CrossRef]

14. Barcik, Š.; Gašparík, M.; Razumov, E.Y. Effect of thermal modification on the colour changes of oak wood. Wood Res. 2015, 60, 385-396.

15. Klaric, K.; Greger, K.; Klaric, M.; Andric, T.; Hitka, M.; Kropivsek, J. An exploratory assessment of FSC chain of custody certification benefits in croatian wood industry. Drona Ind. 2016, 67, 241-248. [CrossRef]

16. Výbohová, E.; Geffertová, J.; Geffert, A. Impact of steaming on the chemical composicion of maple wood. BioResources 2018, 13, 5862-5874. [CrossRef]

17. Banski, A.; Kminiak, R. Influence of the thickness of removed layer on granulometric composition of chips when milling oak blanks on the CNC machining center. Trieskové A Beztrieskové Obrábanie Dreva 2018, 11, 23-30.

18. Kminiak, R.; Banski, A. Separation of exhausted chips from a CNC machining center in Filter FR-SP 50/4 with Finet PES 4 Fabric. AIP Conf. Proc. 2018, 020011. [CrossRef]

19. Hejma, J. Vzduchotechnika v Dřevozpracovávajícím Průmyslu; SNTL: Praha, Czech Republic, 1981; p. 398.

20. Dzurenda, L.; Orlowski, K.; Grzeskiewicz, M. Effect of thermel modification of oak wood on sawdust granularity. Drona Ind. 2010, 61, 89-94.

21. Dzurenda, L.; Orlowski, K. The effect of thermal modification of ash wood on granularity and homogeneity of sawdust in the sawing process on a sash gang saw PRW 15-M in view of its technological usefulness. Drewno 2011, 54, 27-37.

22. Očkajová, A.; Banski, A. Granulometria drevného brúsneho prachu z úzko-pásovej brúsky. Acta Facultatis Xylologiae Zvolen res Publica Slovaca 2013, 55, 85-89.

23. Hlásková, L.; Rogozinski, T.; Kopecký, Z. Influence of feed speed on the content of fine dust during cutting of two-side-laminated particleboards. Drvna Ind. 2016, 67, 9-15. [CrossRef]

24. Marková, I.; Ladomerský, J.; Hroncová, E.; Mračková, E. Thermal parameters of beech wood dust. BioResources 2018, 13, 3098-3109. [CrossRef]

25. Igaz, R.; Kminiak, R.; Krišt'ák, L'.; Němec, M.; Gergel', T. Methodology of Temperature Monitoring in the Process of CNC Machining of Solid Wood. Sustainability 2019, 11, 95. [CrossRef]

26. Očkajová, A.; Kučerka, M.; Krišták, L'.; Igaz, R. Granulometric analysis of sanding dust from selected wood species. BioResources 2018, 13, 7481-7495. [CrossRef]

27. Dzurenda, L. Vzduchotechnická Doprava a Separácia Dezintegrovanej Drevnej Hmoty; TU vo Zvolene: Zvolen, Slovakia, 2002; p. 143. ISBN 80-228-1212-9.

28. Palmqvist, J.; Gustafsson, S.I. Emission of dust in planning and milling of wood. Holz als Roh und Werkst 1999, 57, 164-170. [CrossRef] 
29. Očkajová, A.; Beljo Lučić, R.; Cavlović, A.; Terenòvá, J. Reduction of dustiness in sawing wood by universal circular saw. Drona Ind. 2006, 57, 119-126.

30. Ratnasingam, J.; Scholz, F.; Natthondan, V. Particle size distribution of wood dust in rubberwood (Hevea brasiliensis) furniture manufacturing. Eur. J. Wood Wood Prod. 2010, 68, 241-242. [CrossRef]

31. Fujimoto, K.; Takano, T.; Okumura, S. Difference in mass concentration of airborne dust during circular sawing of five wood-based materials. J. Wood Sci. 2011, 57, 149-154. [CrossRef]

32. Hlásková, L'.; Rogozinski, T.; Dolny, S.; Kopeckỳ, Z.; Jedinák, M. Content of respirable and inhalable fractions in dust created while sawing beech wood and its modifications. Drewno 2015, 58, 135-146.

33. Očkajová, A.; Kučerka, M.; Banski, A.; Rogoziński, T. Factors affecting the granularity of wood dust particles. Chip Chipless Woodwork. Process. 2016, 10, 137-144.

34. Gefertová, J.; Gefert, A.; Výbohová, E. Chemical changes of selected hardwood species in the process of thermal modification by saturated water steam. Trieskové A Beztrieskové Obrábanie Dreva 2018, 11, 257-264.

2019 by the authors. Licensee MDPI, Basel, Switzerland. This article is an open access article distributed under the terms and conditions of the Creative Commons Attribution (CC BY) license (http:// creativecommons.org/licenses/by/4.0/). 